\title{
45.
}

$611 \cdot 37-013$

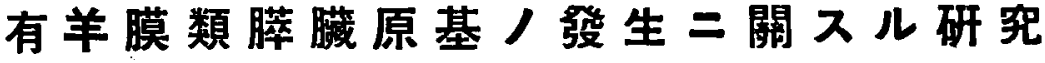 \\ （爬蟲類蝮蛇二於ヶル檢索）}

同山醫科大學解剖學教室胎生學研究室 (主任数波教授)

\section{田坂 三友}

[昭和 16 年 2 月 15 日受稿]

\section{第1章 緒 論}

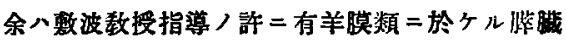

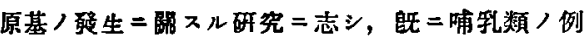

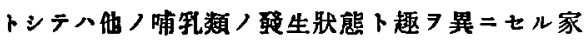

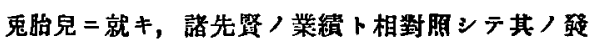
生狀態 7 研究シ，從束哺釈類及ピ人類 =於ケル腹 腾原基ガ，有對性二登生スルモノナリヤ否ヤノ問 题 =䍊シ，哺乳類＝於テ八敷波教授，村上氏等， 唱フルガ如ク家鬼脂兒二於テモ亦有䍌性二路生 ルモノナルコトヨ明カニシ，殊二家鬼二於テハ腹

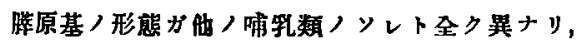
管腔㩆 カニシテ既二本誌上二资表シタリ. 更二亦比較强

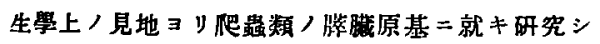

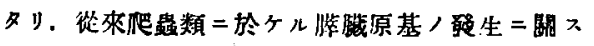
ル報告ノ主ナルモノ八 Rathke, Hoffmann, Saint-Remy, Brachet, Völker, Tecqmann, Weber, Siwe, 大橋諸氏/外近時我力数波数空=

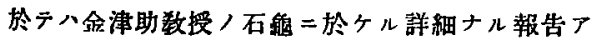

リ. 而シテ之等諸學者八背腾原基，1筒ナル點= 就テハ各人其ノ所見ノ一敌七ル處ナルモ，腹䇾原

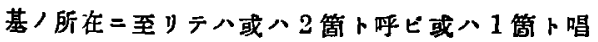
へ，及八其/登生 7 否定セルモノアリテ，各々矼

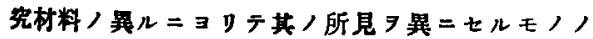
如シ.

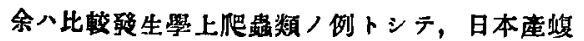

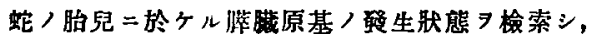
之等諸先㹂ノ報告卜比較检討 コレラ芠ニ報告セントス。

\section{第 2 章 材料及ビ檢索方法}

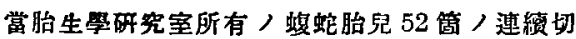
片標本中，余ガ研究二必要ナル登生階梯二在几モ ノフ選出シテ检索二资セリ。

標本製作方法トシテハ總テ新鮮ナル胎兒 オルマリン水」 凤八Zenker 氏夜=テ固定シ， Borax-Karmin $=$ Stückfärbung 7 ナ, 所定 ノ方法ヨ程テ「バライン」ニテ包埋シ,コレタ $10 \mu$ 連経橫㡭切片トナシタルモノナリ.

槙製镆型製作方法トシテ八，必要部分，切片 Edinger 氏 Zeichenapparat $=3 リ テ 100$ 倍 又八 50 倍=掂大模䉣シテ、コレ $1.0 \mathrm{~mm}$, 又八

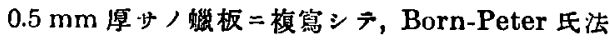

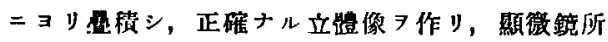
見卜数比シテ你細二其，發生狀態习研究シタルモ ノナ・

\section{第 3 章 各發生階梯二於ケル膵䓪原基} 觀察

芽 1 階楼 胎兒番號 Nr. 34 長徑 $2.5 \mathrm{~mm}$ 胎胃ノ外形八衉曲甚シク，頭部八腹方二盾シ頭 部ノ腹例八胸部=接シ，尾部又防方二彎曲シテ尾 
端八腹部二接着ス，前，中， Fig. 1. A

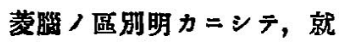

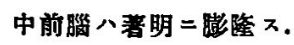

頑器八综登生眼胞 7 形成 シ水晶體原基八水晶蹬产, 狀 = 在り. 誑器八未ダ国形 ノ㥁胞 7 形成スル =過ズ.

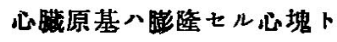
シテ認メラレルノミニシテ 未ダ房室ノ區別不明ナリ.

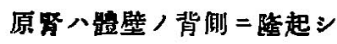
テ大動脈/左右外方 7 尾方 二走リ，原筲小管八僅二蝶

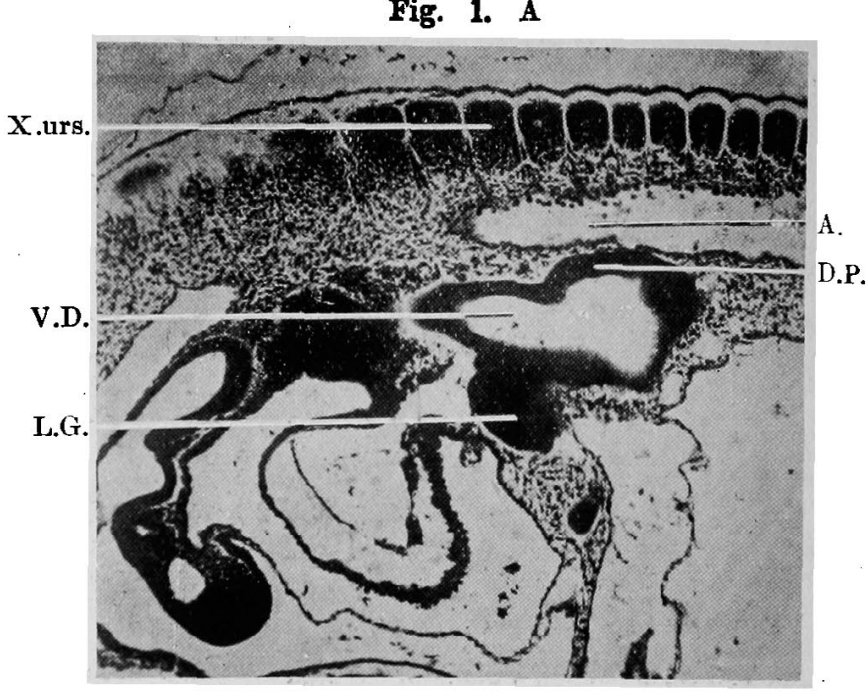
曲ンテー部原筒管二通ズ.

肝管八第 10 原節ノ高女二於テ腸管ノ䧗侧 $=$ 開口天.

肝管ノ開口部ヨリ僅カ尾方二於とル腸管、 橡斷面 7 見ル = Fig. 1. $\mathbf{A}=$ 示 スガ如ク第 11 -13原篩ノ高サ＝於テ 八中脰頭端，背侧壁 八腸管壁ノ他ノ部二於ケルョリモ肥厚筧殖シ テ，僅二背方 $=$ 膨出 スル 7 見儿。コ，膨出部 ヘ郎チ背膦原基ノ發生地ナリ。サレド末タ

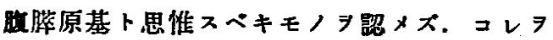
模型 $=$ 就キ見ル = Fig. 1. B =示ス如夕陽管 ノ腹侧二於テ八肝管八肝原基 $リ$ 出デテ儤管 =開口シ，肝管ノ開孔部 $\Xi$ リ㮖力尾方中腸频 端背侧 =於テ，腸管壁八嚾=背方二膨隆シテ 背谐原基 7 特

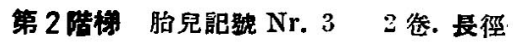
$4.0 \mathrm{~mm}$ 弱

胎兒八頭部胸部二接シテ右侧二迴旋せルコ

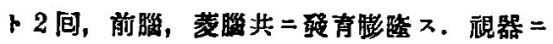
於テ八水晶體末米水晶能萑/狀能二在リ。鳃器八 稍々棈圆形ノ㯖胞 7 形成 ナル心塊トナリ，中渴ハ末ダ腸管 7 形成スル二至

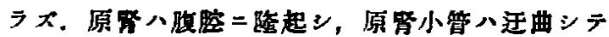

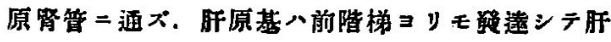

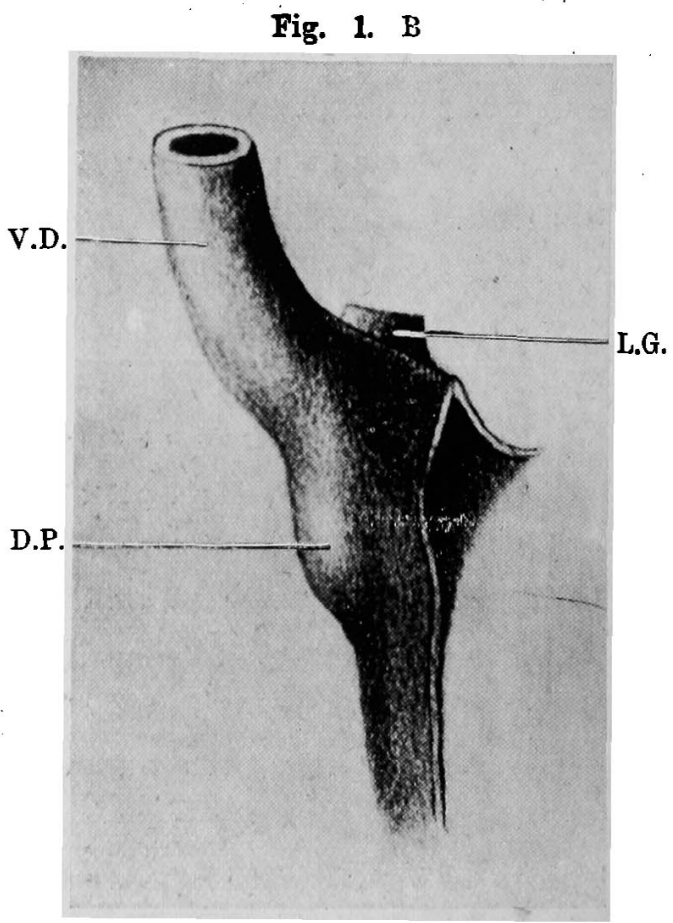

管八右背頭方 ヨリ第 渎侧右方二開口ス。

背膀原基八第 11 乃至 13 原節/高サ／間 Fig. 2.

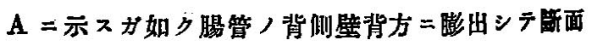

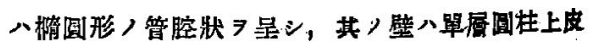




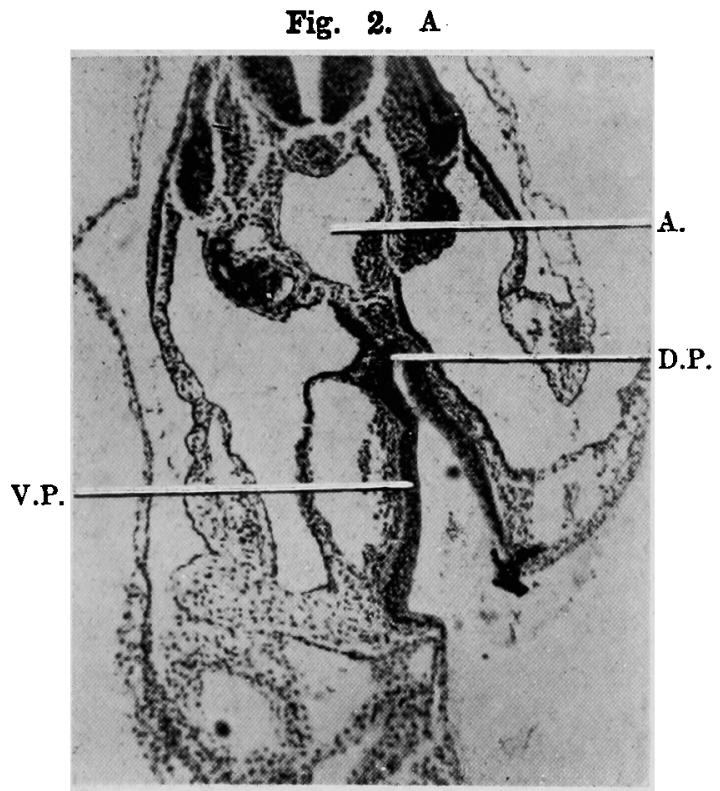

Fig. 2. B

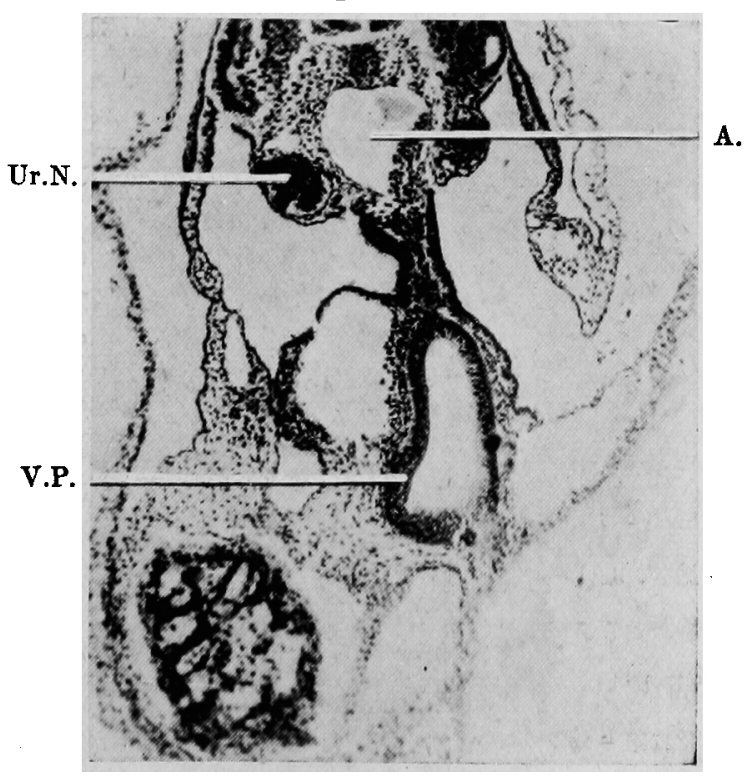


シリナル。的管尾端第 10 乃至 12 原節ノ高廿二於テ，腸管腹侧右方 八Fig. 2. B =示スガ如ク助方

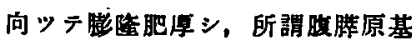

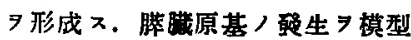
二就テ見几 = Fig. 2. C =見儿如 ク背搭原基八肝管力腈管 =開口七 ル部 $コ$ リ稳々尾方，高廿二於テ， 第1階梯二於ケルヨリモ更二腸管 八背侧 ミリ背方二向ッテ扁平ナル

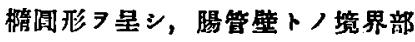
八校扼セラレテコノ部习国繌スル

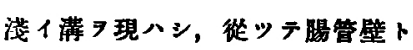
八明カ二區別スルコト习得. 䐜搭 原基八肝管，尾端尾方二於示得管 儿腹倒右方 $=$ 半球狀 $=$ 隆起 .

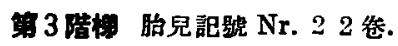
- 長徑 $4.0 \mathrm{~mm}$

胎胃八烸曲甚ンク，頭部八腹侧 二届曲シ，其，腹倒八的部二接着 シ，尾部又㨫方二䢙旋シテ胎見， 右㑡 $=$ 至 $\pi$.

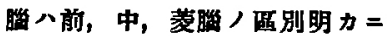
シテ眼盃八丙外 2 層ヨリナり，水 晶䯘八, 眼盃ノ中

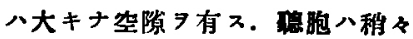

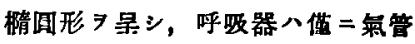

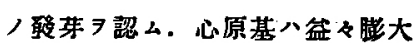
スルモ是室ノ區別明カナラズ．原 㫮八大動脈／右侧 ニアリテ原照丘 尹形成之，原督小前階梯 ヨy モ更二智曲シテ原觜管二通ズ．肝 原基八次第二登育ン旰原基八右頭 方 3 y次第 $=$ 尾方＝至》第 10 原

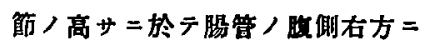
䦩口ス。
Fig. 2. C

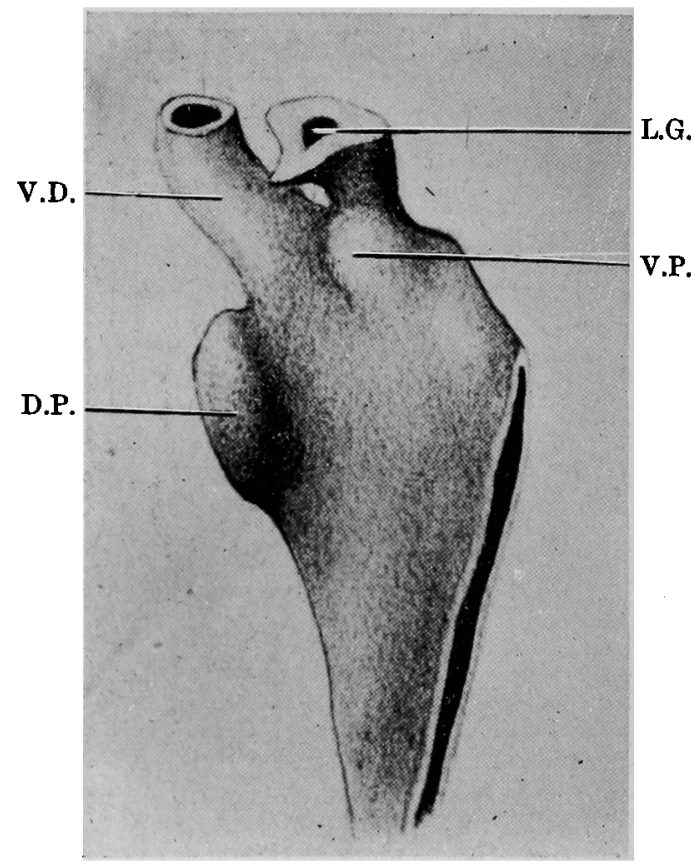

Fig. 3. A

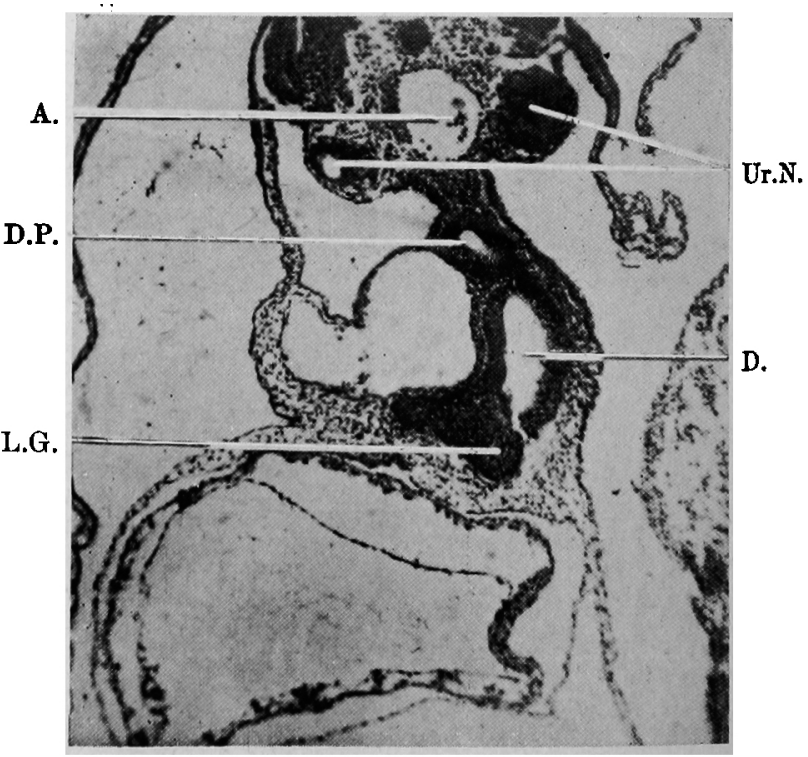


背膦原基 第 10 原節ノ尾端

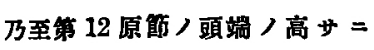
於テ Fig. 3. $\mathbf{A}=$ 示スガ如ク腸 管 背側 $コ$ リ背右方 $=$ 向ツテ膨 出シテ，其ノ㽬端八僅＝圆形ノ 管腔狀 7 呈 $ᄌ$.

䐜荟原基八第 10 原䬦 $ノ$ 高廿 =於テ䚽原基ノ腸管開口部ノ尾

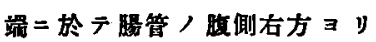
Fig. 3. B =見ルガ如ク䐜方 $=$ 向ッテ膨出ス. 之ョ模型 $=$ 見ル = Fig. 3. C / 如ク肝原基八腸 管入腹側二於テ右頭方 $\exists$ り次第 =尾方二至 vテ晹管，位㑡右方 =閉口 ，背搭原基八胡搭原基 ノ桷々頭方ノ高サ＝於ヶル渴管 八背壁ヨリ背方川膨出シテ, 其 ノ頭方部八晹管 ヨyノ校管琴象 著明ニンテ Fig. 3. $\mathrm{C}=$ 見儿如 其八頭端八管腔狀 7 呈ス。䧗 菜原基八肝管ノ尾端二於下腸管 人㬴側 3 У Fig. 3. $\mathrm{C}=$ 示 $ᄌ$ 如

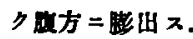

第 4 陵楼 胎兒钯鯱 Nr. 36

3 管. 長徑 $4.0 \mathrm{~mm}$ 强 胎完八新階梯 $コ$ リモ更二登青 進展ンテ, 右側二先クコト3 国 =及ビ，頭部ハ甚ンク届曲シテ 胸部二接青シ，膇モ又前階梯 $\exists$ リモ更二能造ン，䰝器八眼盃內 外 2 屌ヨリナリ，水晶鳁八球形 ヨ呈ン中心部二佁ホ大ナ几空箵 $\boldsymbol{7}$ 有 吸原基へ前腸 $\mathbf{y}$ 出デテ前階梯 ヨリモ更二路青シテ管腔狀 7 旺 湔渴 ノ渎方 9 尾方 $=$ 向 7 . 㫮

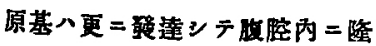

Fig. 3. $B$

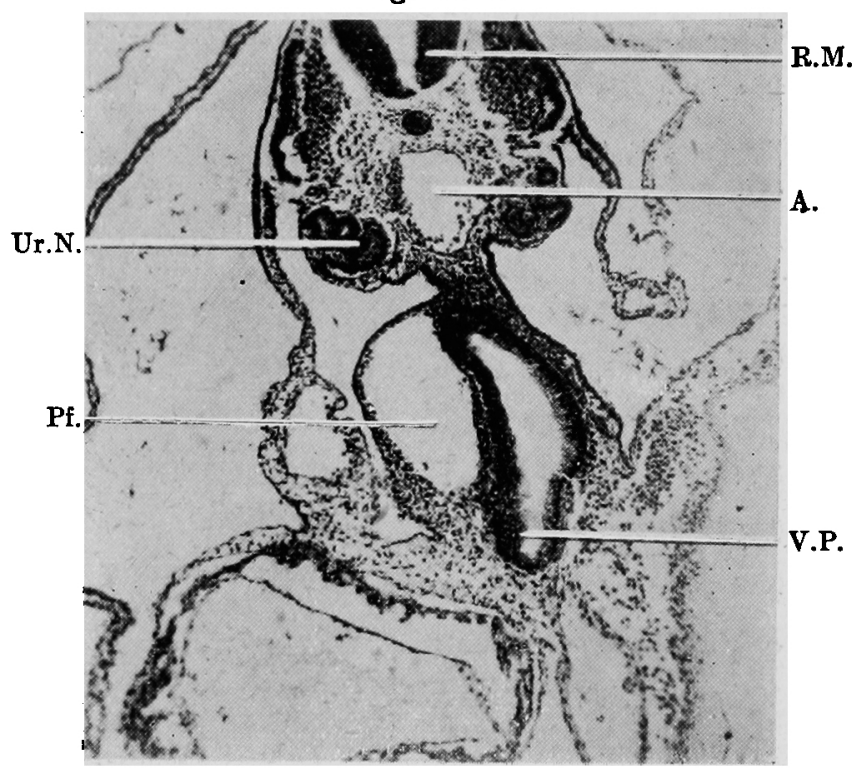

Fig. 3. C

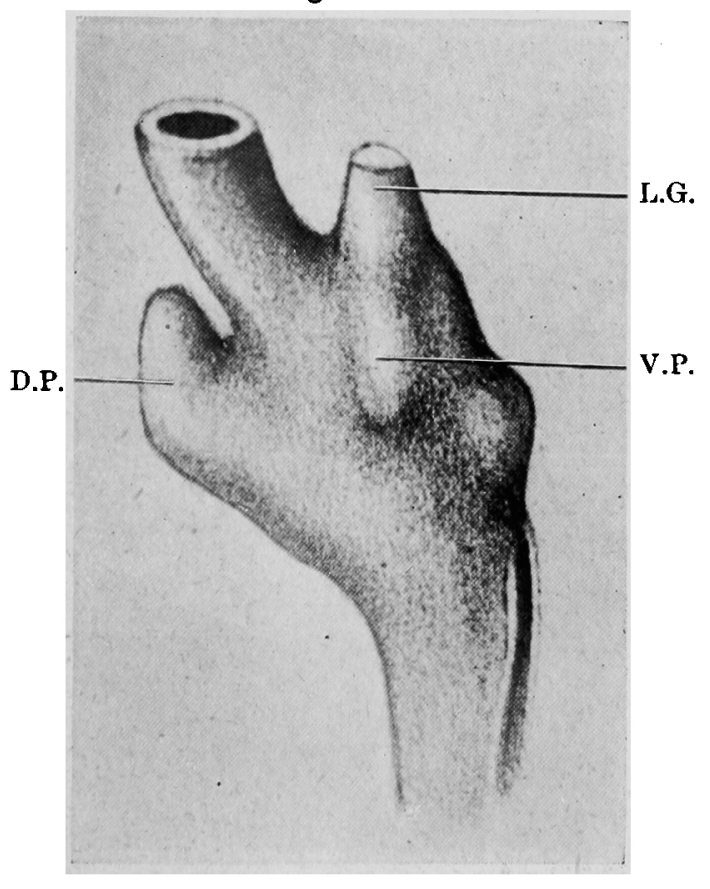


起シ，原觜小管ハ迁曲シテ原觜二。

スル。

肝原基八諸々 =細胞索 > 存在 ルヨ認メ，肝管八腸/台侧頭方

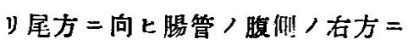
於テ腸管二入ル。

北櫒原基八所管，䁑管二開口七 ル部ノ高サニ於テ腸管ノ背侧右方 ヨり管腟狀 ヨ是シテ門脈，左㑡" 沿七テ背頭方二至り, 稍々膨大シ テ盲管狀 二終ル (Fig. 4. A). 而シ

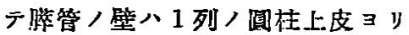
ナり頭端ニ八㹽多ノ細胞ノMitose 見ル．腹灌原基八肝管，腸管關口 部／尾端 =於テ腸管壁／腹側右方 二於テ Fig. 4. B =見儿如腹方 二膨隆ス.コレア模型 $=$ 見ル二背 膵原基八晹管 $コ$ リ繀窄現象著シ ク進展シ，腹荟原基/僅二頭方， 位置二於示腸管 /背㑡 3 リ長亿單 管狀 先端八僅 =缕大入，肝管八腸管， 右側背頭方 3 リ背脽原基，晹管一 ，開口部卜略ボ同ジ高せ＝於テ腸 管入䧗倒右方二入リ，腹测原基八 Fig. 4. $\mathrm{C}=$ 見儿如ク肝管，尾端 二於テ，晹管，腹侧右方二前階梯 ヨリモ更二右方二闽形二隆起 .

第 5 階枒 胎兒番號 Nr. 42

\section{3 然, 畏徑 $3.5 \mathrm{~mm}$}

胎兒八頭部屈曲シテ右何二㣞ク

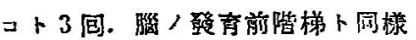
シシテ，視器八眼盃队外2 層卜ナ リテ，水晶體八眼盃ノ中二在りテ 球形 7 荘シ中央二大ナル空隐 7 有 シ，疆胞八前階梯 ヨリモ稚々分化

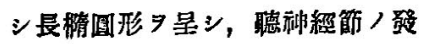

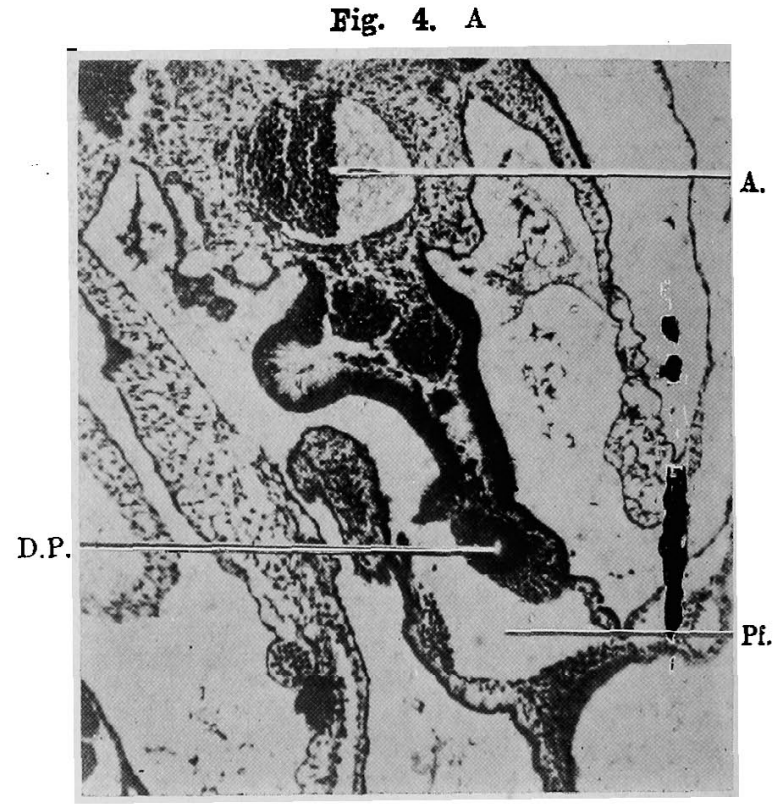

Fig. 4. B

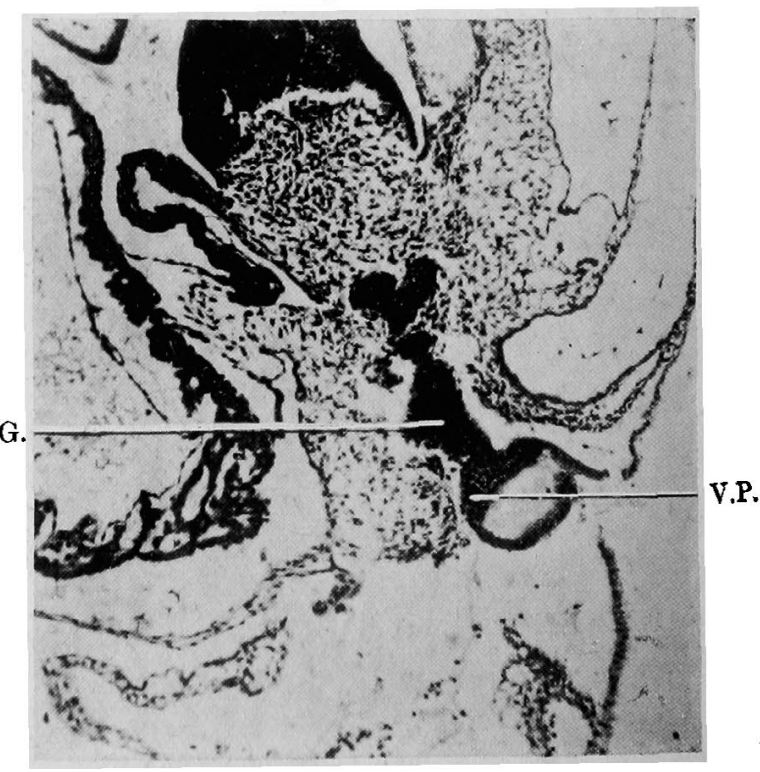


Fig. 4. $\mathrm{C}$

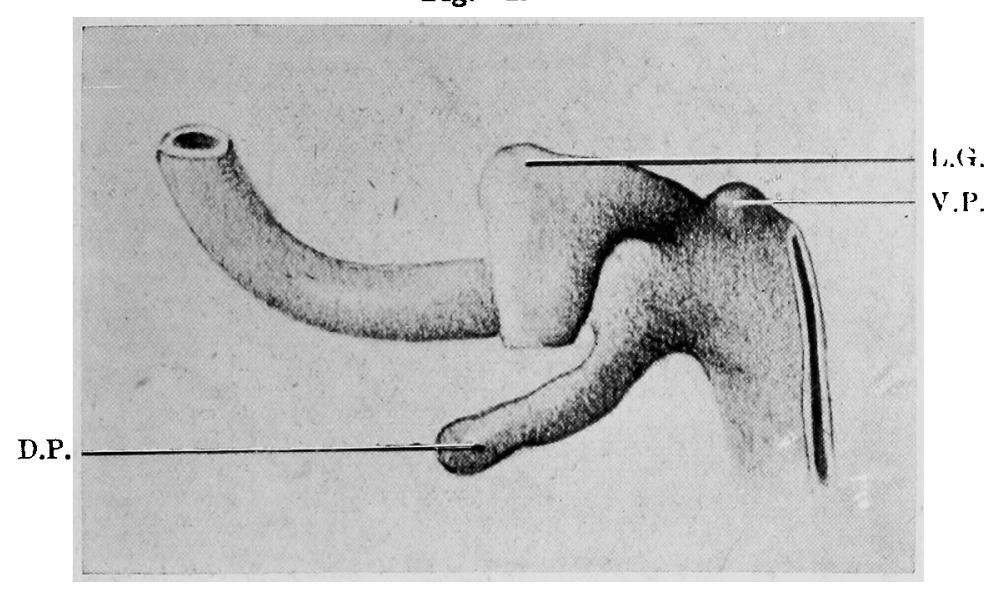

澾セルョ認ム、心原基八益々膨火シテ

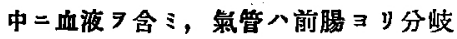
シテ管腔狀 7 呈シ尾方二向フ。原腎八

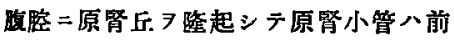
階梯ヨリモ更二过曲シテ W 氏管二入 ル. 肔原基八前階梯 ヨリモ稍々登澾シ テ肝管八右頭方 $ヨ$ リ晹管, 值僛右方 $=$ 入ル.

背㗪原基八肝管ガ腸管二開口七ル高 廿二於テ，腸管，背侧稍々右方ョリ管 腟狀 ヨナンテ背方二進ミ，其ノ管壁八 單屏國柱上皮ヨリナリ門脈，左侧二沿 ヒテ背頭方二進ミFig. 5. $A=$ 示ス如 ク門脈 背方二至り膨隆シテ，侐二腺

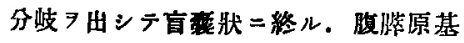
八前階梯 $コ$ モ僅二肔管尾端二近揚 管，䐈側壁ョリFig. 5. B =思儿如ク 腹方二膨隆 型二見ル=背搭原基八管腔狀 7 是シ腸 A.

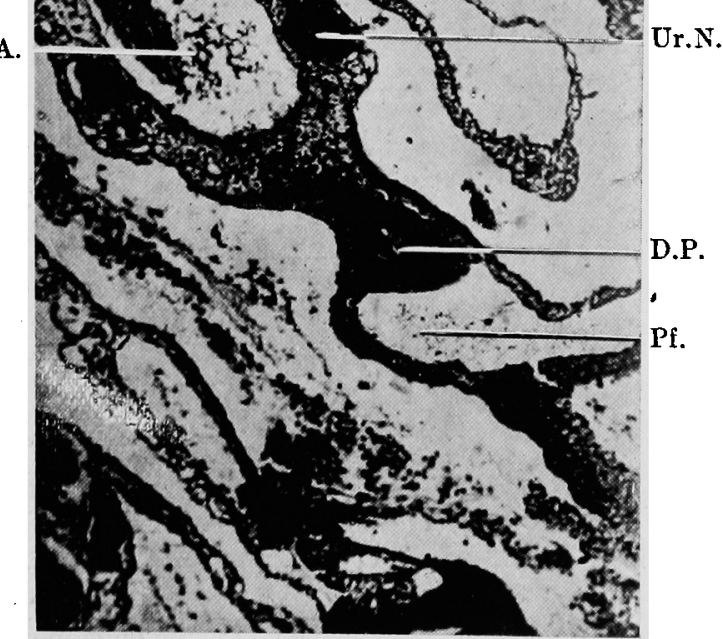
Fig. 5. A

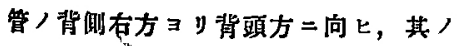
先端八膨隆シテ盲葚狀二終ル. 而シテ 其ノ先端部ニ少ンク出凹 7 現ハス、コ レ分岐ノ初兆ナラン，腹整原基八朋管，尾端晹管

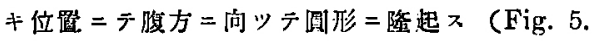

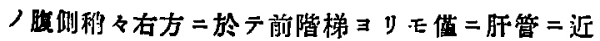
C). 
Fig. 5. B

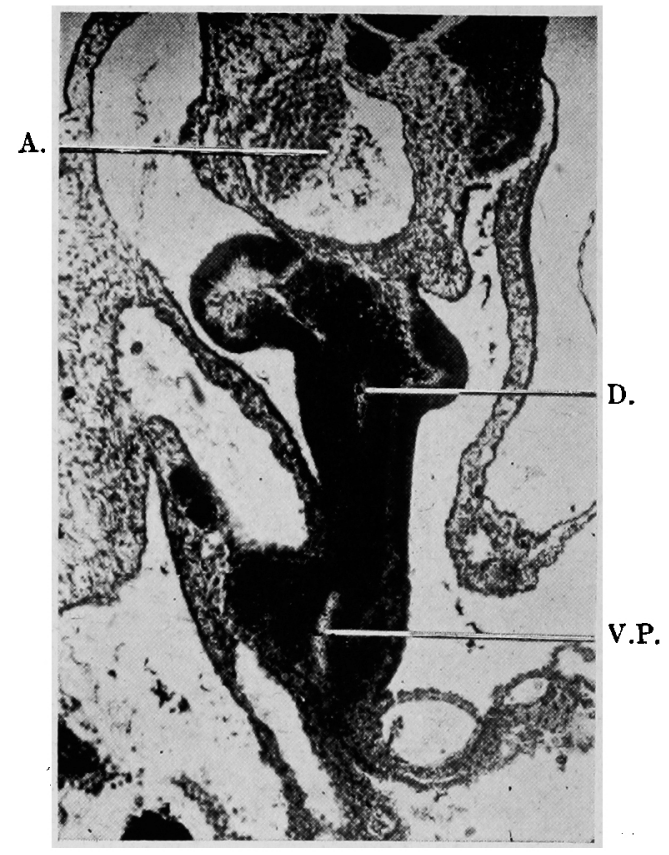

Fig. 5. C

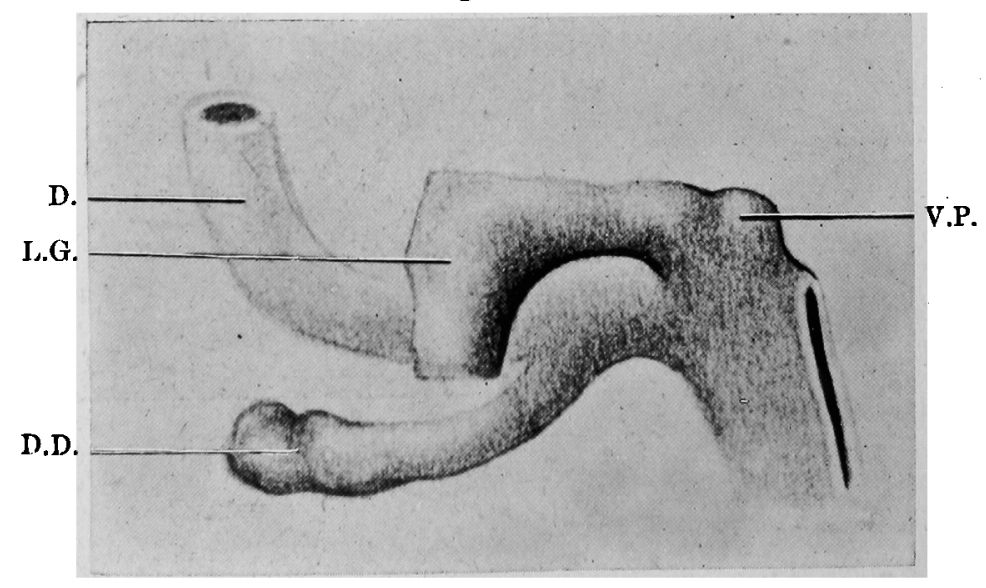




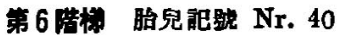

$35 / 2$ 憭. 展徑 $4.5 \mathrm{~mm}$

胎胃ノ外形ハ頭部屆曲シテ眴部二接 着シ右㑡二卷クコト $3 x / 2$ 焱. 朔八前階

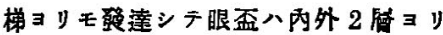

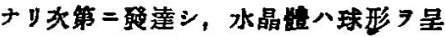
ン中心部 $=$ 牛月形 $/$ 空隚 7 有 $ス$. 德胞 八撼形 $习$ 是シ僅 = 內淋巴管原基 7 認 4. 氣管八前腸 $コ$ リ分離シテ管珤 ン前階梯ョりモ更二長ク尾方二走り，

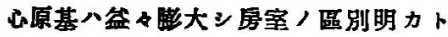

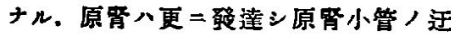
西甚シク，中腸八閉鋇シテ管卧狀 7 呈

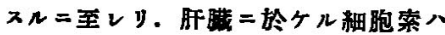

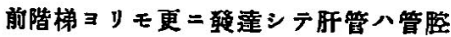

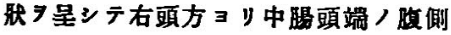
右方 $=$ 入几

背愺原基八略ボ肝管/腸管開口部， 高サ＝於ヶル晹管ノ背侧右方 $コ$ リ圆形 管爿ノ滕管トナリテ背方二向ヒ，門脈 ノ左剆ニ接ンテ背頭方 =進ミ Fig. 6. B =見ル如ク門腿ノ背湖二至リテ次第 $=$ 膨大シテ多クノ腺 ヨ分帔シテ其/周国 八細胞二テ被ハル，腹梣原基八前階梯 二見タルガ如ク肝管，尾端二於六儿腸 管ノ政侧壁ニハ之ョ証ムルコト能八

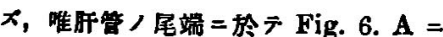

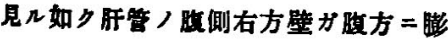

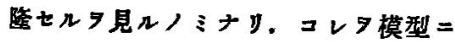

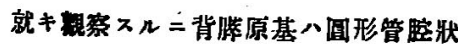
シナンテ渴管ノ背側右方ョリ背方二出 デ䅌々右方=俑シテ Fig. 6. $\mathrm{C}=$ 示 ガ如り, 前階梯 $コ$ り更二長ク背頭方 $=$ 问七，其/先端八前階梯ヨリモ更二膨 大 .

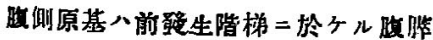
原基部タル肝管尾部二於ケル渴管
Fig. 6. A

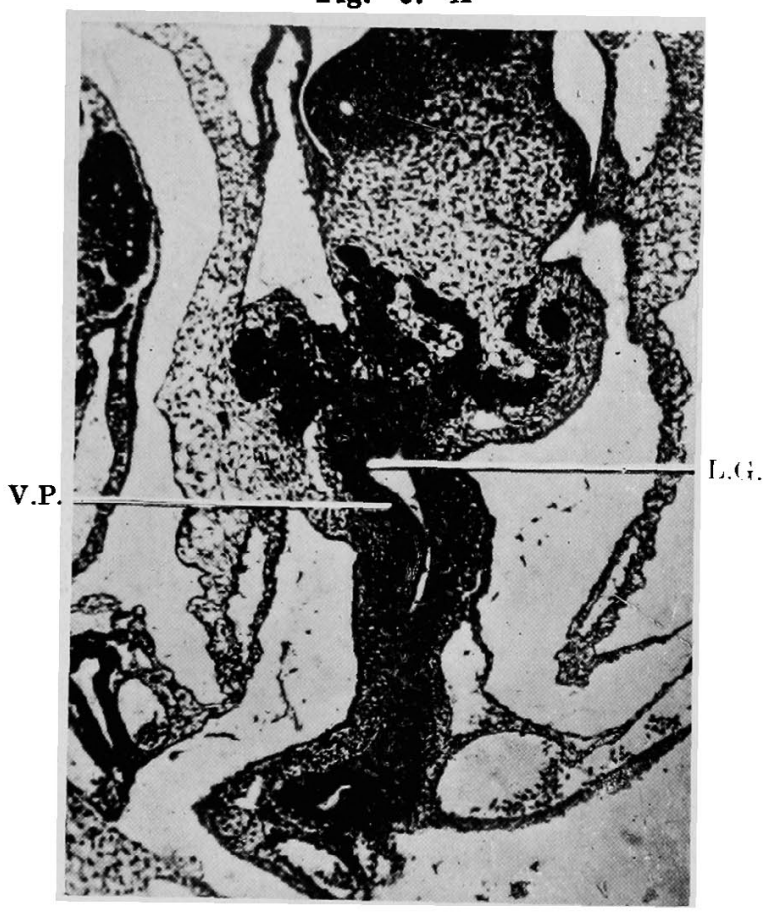

Fig. 6. B

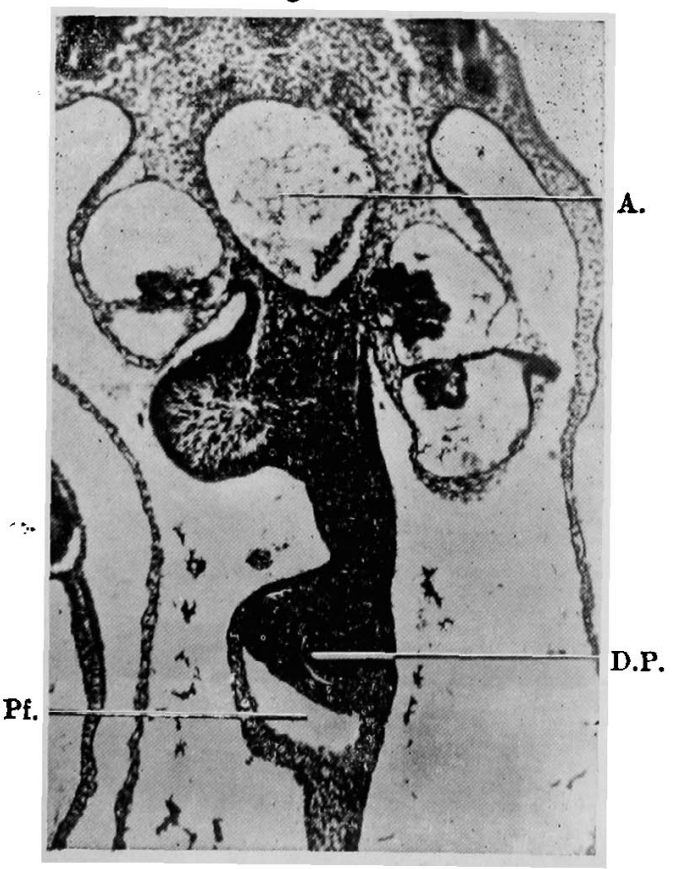


Fig. 6. $\mathrm{C}$

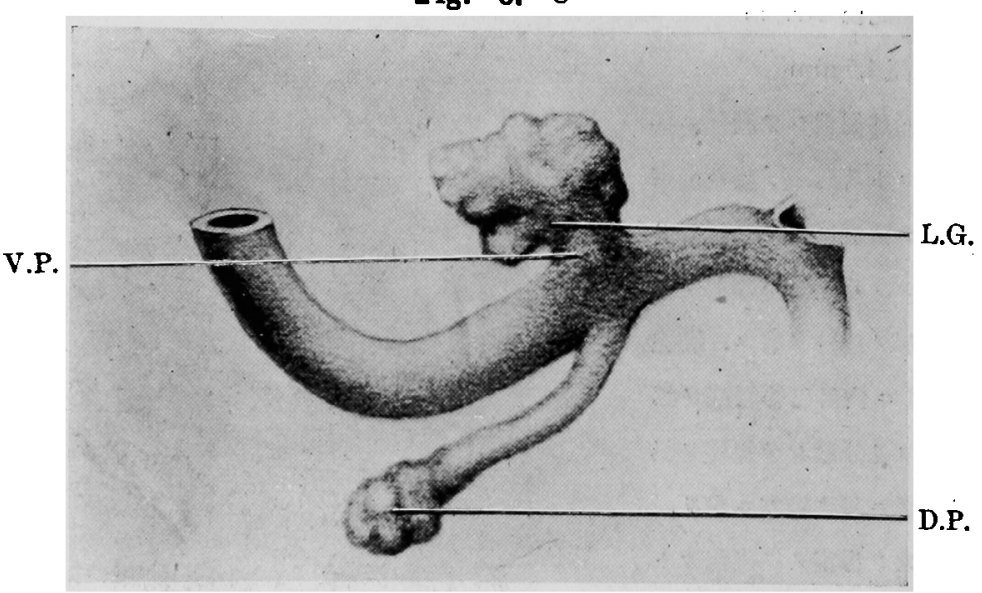

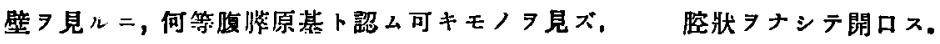

唯肝管 /尾端二於テ僅=䧗方=膨隆セ儿小隆起 7 背搭原基八肝管ガ腸管 =開ロセル高サニ於くル 見ルノミナリ．郎千腹臎原基八本階梯二於元八左 腸管, 背湖二於テ Fig. 7. $\mathrm{A}=$ 見ル如方右方 方ニ八出現七ズ, 右方二於デミ存在

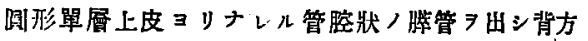
モコノ右腹膵原基モコノ階梯二至しバ前晔梯二比 =向七門脈 /左瞅＝至り，多クノ腺 シテ著シク退化菱縮シ，只僅二之二相當スル部位. 頡方 $=$ 進ミ䦥脈，背㑡 =至りテFig. 7. B =示 二於ケル腸管壁ノ微カナル膨隆ニヨリテ其/存在 如ク前階梯二於ケルコリモ更二多クノ腺 7 分岐シ ヨ認メ得ルノミナリ。

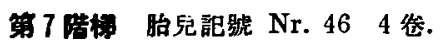

長徑 $5.5 \mathrm{~mm}$

胎兄ノ外形八頭部西曲シテ胸部二接 シ，右甽 $=4$ 夋シ $テ$ 前, 中, 蔆腦 $/$ 發 泾, 前階梯ヨリモ著シク, 視器二於テ

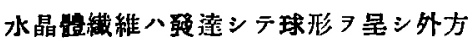
二近ク侻二牛月狀 ，Lumen 7 認么, 䁬胞八荾形 7 是 $シ$ 内淋巴管原基 7 認 ム. 氣管八前晹 $\boldsymbol{3}$ y分離ン管腔狀 7 是 ン前階梯 $コ$ リモ更二長ク尾方二向ヒ,

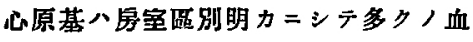
液 7 合ミ胸部二膨比ス。原筲八龵シク 酸迲ンテ原留小管八著シク迁曲ス。肝 原基ハ盆々發達シテ zellbalken，分 化薜シク又瞊愿基 7 認么，肝管八 右頭方 $ョ$ y 3 筒，管 肝管トナリテ晹，腹倒右方二圆形，管

Fig. 7. A

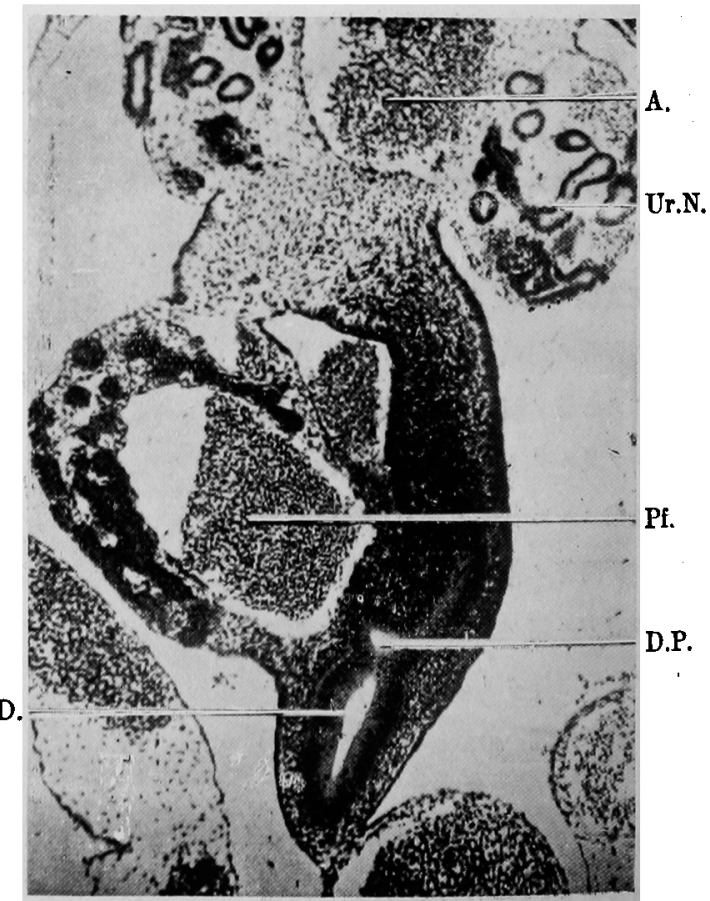


テ終り，其ノ周国八細胞群 被八n，脽滕原基八既二退化消失 シテコレフ認ムルコト能ハズ.コ レ゙模型 $=$ 就キ見ル =背膵原基八 總軨膽管ノ腸管開口部卜略ボ同粎 ノ位置二於ヶル高サ, 泻管背側右 方ョリ, 前階梯ヨリモ稍々小サキ 長徑ノ圆形管腔狀 ～呈七ル搭管 出シ，搭管八背頍方二向ヒテ進 ミ 磌方ハFig. 7. C =示ス如ク前階 梯ヨリモ更二㱅大ス．肔管，尾端

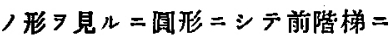
於ケル肝管，尾端二腹腆原基 ノ痕

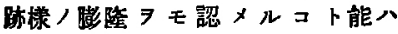
$x$

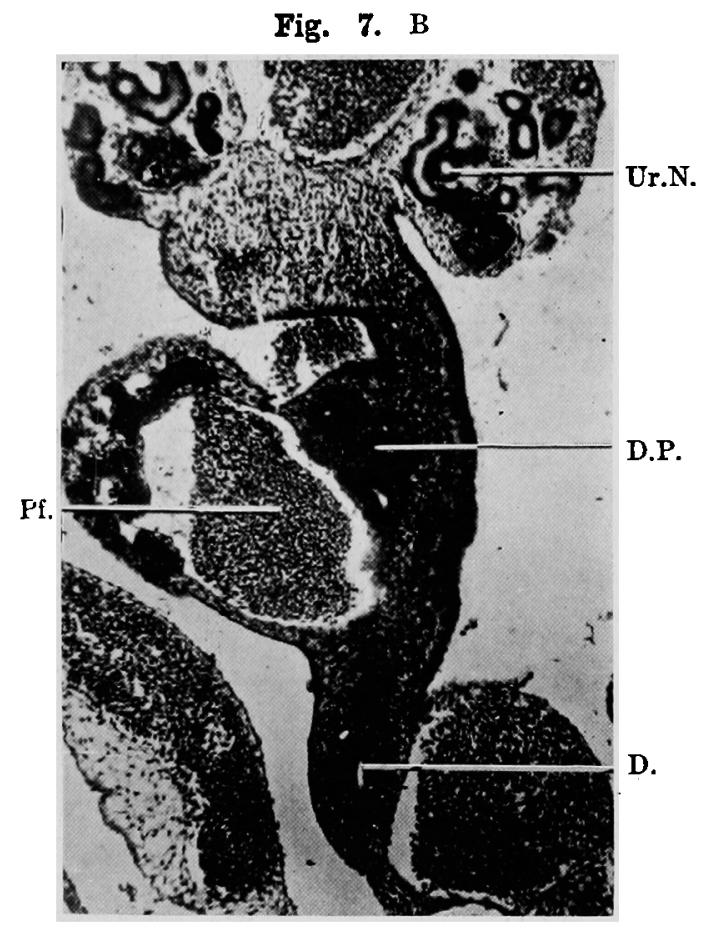

Fig. 7. $\mathrm{C}$

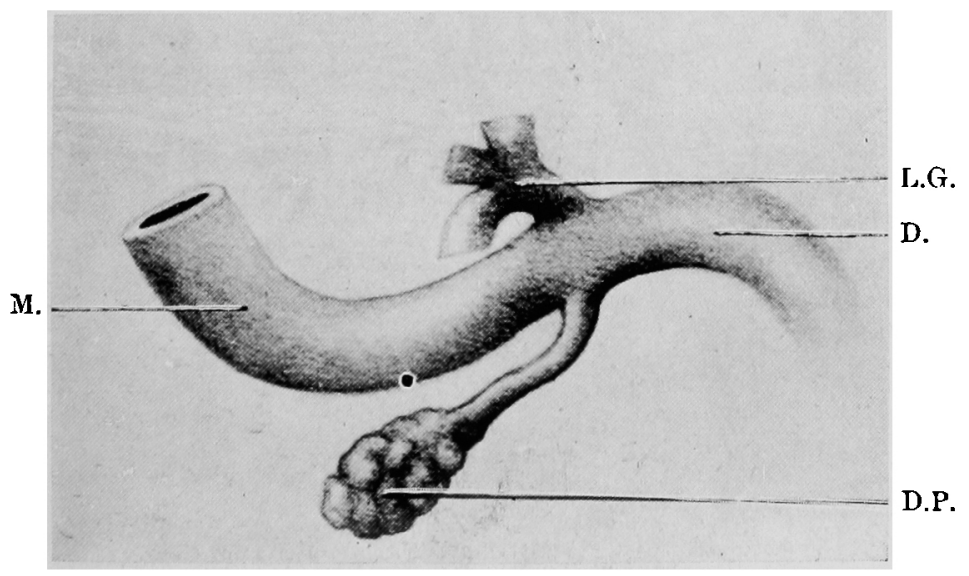

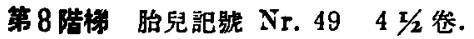
長徑 $6.5 \mathrm{~mm}$

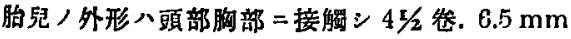

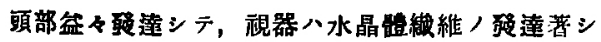

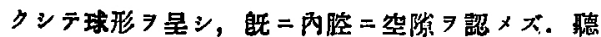
器八内淋巴管原基ノ路迋七ル 認メ，心原基八前 階梯ヨリモ更二分化シテ室壁，筋屡甚ンク房室ノ
品別明カナリ。原筒ハ原简小管，迁曲甚シク多ク 血液ノ分布七ル 7 見ル。肝原基八前階梯 $コ$ リ

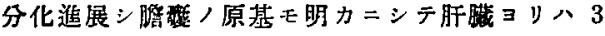

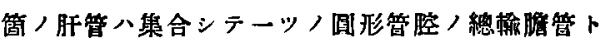
ナリテ晹，腹側右方二開口ス。膲烚原基八前階梯

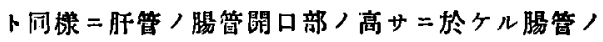

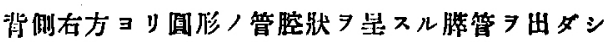


背頭方 $=$ 進ミ，門胙ノ左㑡二至り周图二多クノ腺

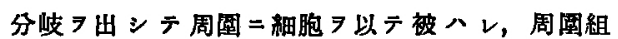
蟣トノ區別明カニシテ更二背頭方＝進ミ，頭端八 Fig. 8. $A=$ 見儿如ク門脈, 背側 $=$ 至》, 前階梯 ヨリモ更二多ク/腺 7 分吱シテ外形八问形习是 ス。模型二就キコレア見ルニ膲践原基八腸管ノ背

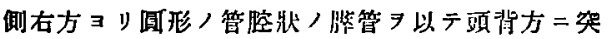

出ン Fig. 8. B =見ル如キ形 9 星ンテ，前階梯ニ 於ヶルヨリモ大サ文ビ長サ 梯 =於テへ背櫵原基八其/先端 $1 / 2$ 部 =於テ腺漛分 岐 不ヒタルモコノ階梯二至レバ其/先端 $2 / 3$ 部=

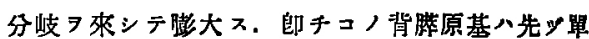
管狀，形態 7 整人，而シテ其ノ先端 $コ$ リ濑次分皮 フ關始スルモノノ如シ.

Fig. 8. A

L.G.

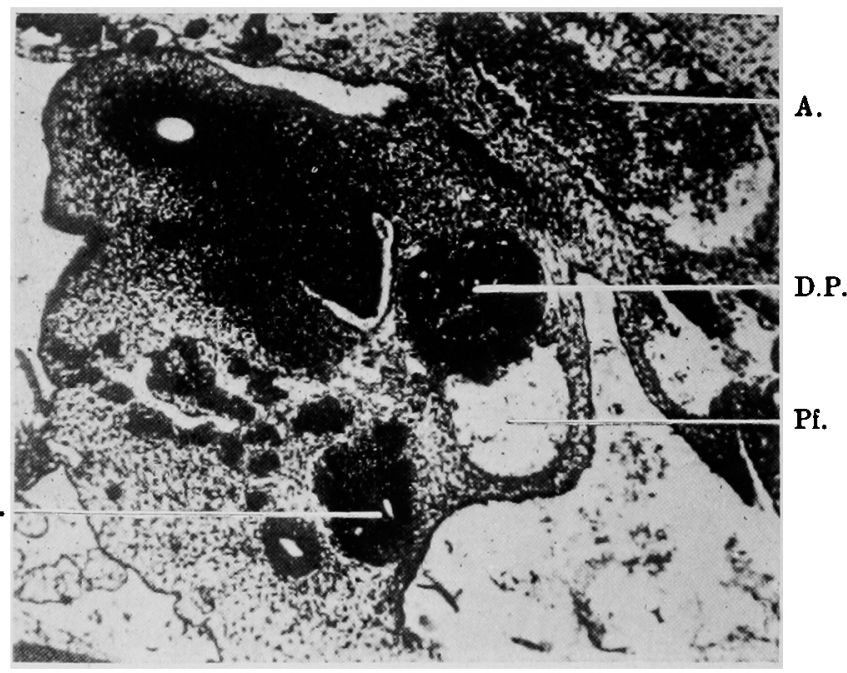

Fig. 8. B

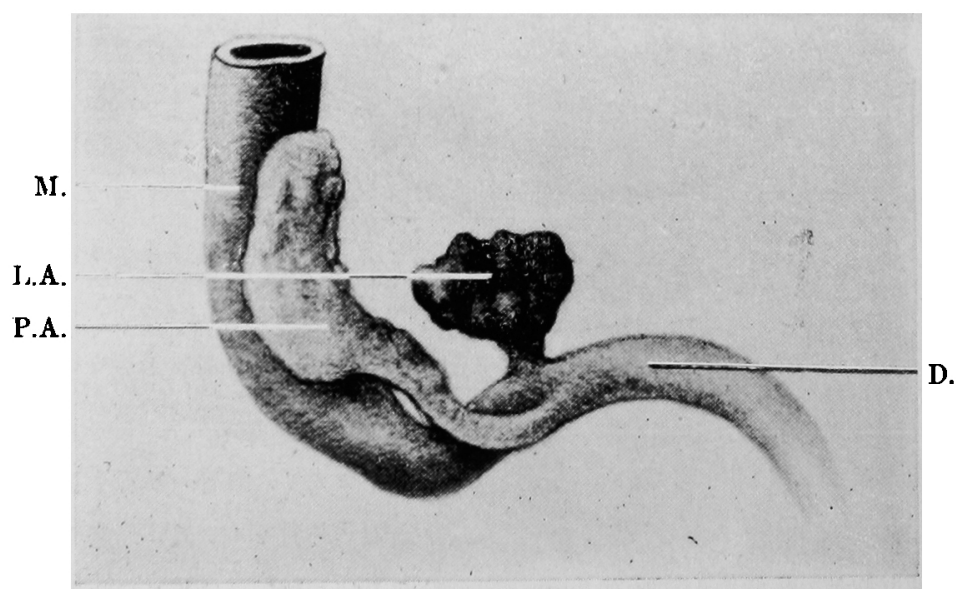

第9嚿梯 胎兒記號 Nr. 334 染.

喂徑 $11.0 \mathrm{~mm}$

胎兒八右側二征クコト4包ニシテ，頭部瓜曲シ
視器 $=$ 於テ八㮶膜二色素 7 認メ, 水晶體八球形

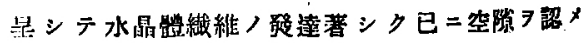

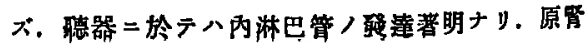


小管ノ迁曲甚シ原筜二於デ諸々二血液

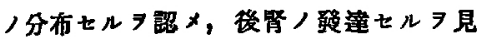

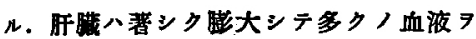

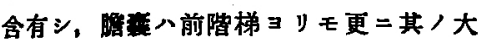

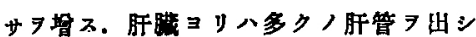
之等八集合シテ1本ノ抙管トナリ，渴管

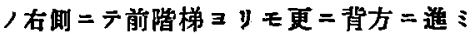
テ Fig. 9. $\mathbf{A}=$ 見ル如ク膵䑏原基ノ開口 部卜同一ノ高サ二於テ睡管二開口ス。䑏 渪原基八Fig. 9. $\mathbf{A}=$ 示スガ如ク腸管ノ

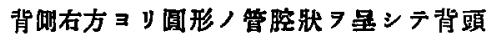
方突出シ，門脈/右侧二至ルヤ前階梯 3 リモ更ニ多クノ腺 ナル. 而シテ門脈，背側＝至リテハ Fig. 9. $\mathbf{A}=$ 示スガ如ク前階梯 3 yモ更二分化

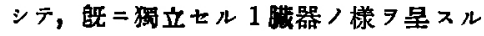

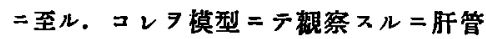
ヘ多クノ小肚管 7 集合シテーツノ圓形ノ

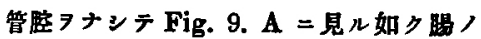
右㑡 =於テ前階梯二於とルョリモ更二苝 告/開口部二近付キテ踶二開口ス。

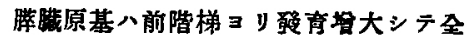

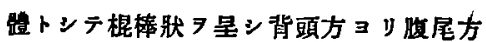
二向七絊キ圆形管狀 /腆管 睡管一八開口部位卜同シ高サニ於テ腸管 /右背側二開口 ス (Fig. 9. B). 而シテ

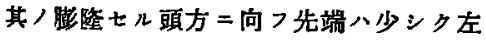
右ノ方向二医セラレタルガ如キ形 ス. 又其/渴開口部 $\Xi y$ 腺分岐部 $=$ 至ル

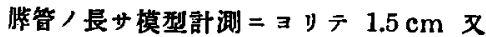
コノ部ョリ蕠腈ノ先端 =至ルマデハ $4 \mathrm{~cm}$

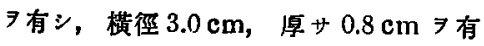
$\pi$.

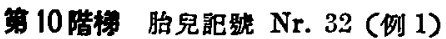
$4 \mathrm{r} / 2$ 得. 長徑 $10.5 \mathrm{~mm}$

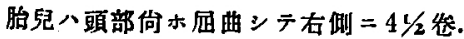
視器二於テハ絧膜ニ八等クノ色素 7 有シ
Fig. 9. A

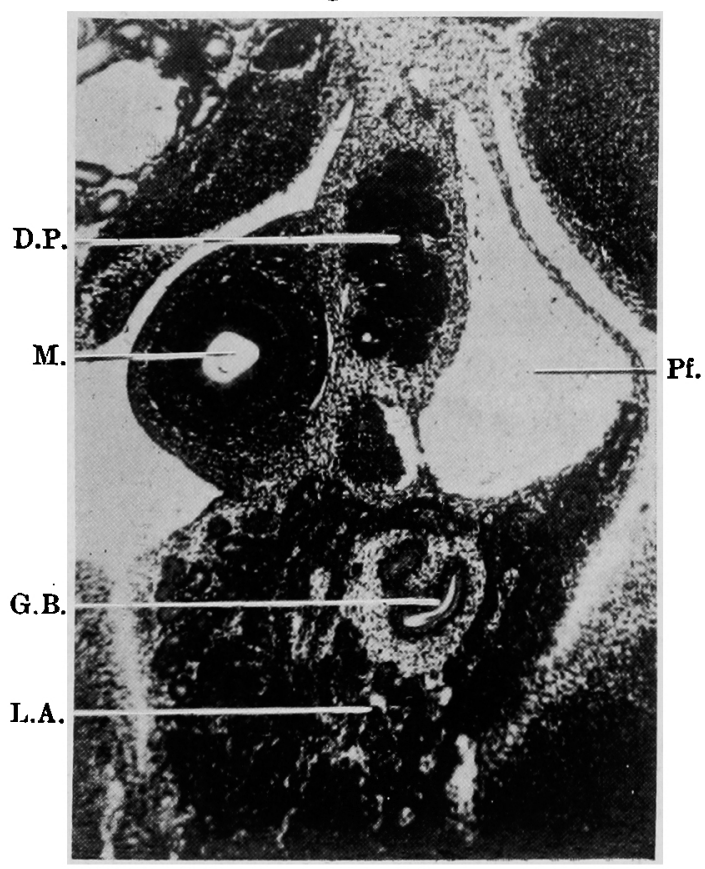

Fig. 9. B

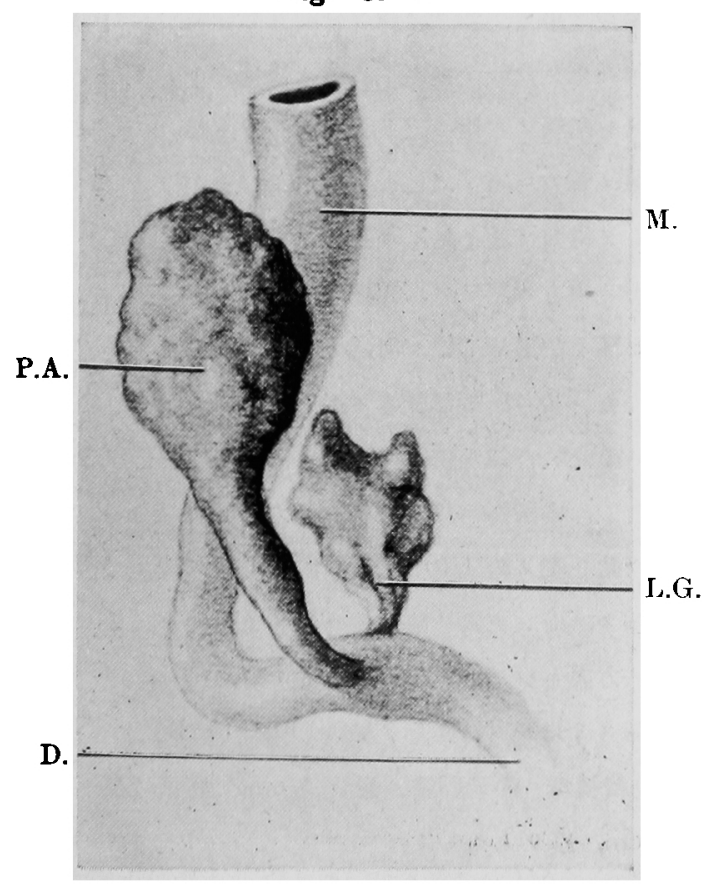


水奛體ノ䄉維ハ著シク Fig. 10. A 分化シ，侅器八內淋巴 管，强洼著明ナリ。胃 原基八前階梯 $コ$ モ更 二膨大トナリ，原腎小 管ハ过曲勘シク多ク， 直䇫ノ分布 7 認 $\times$ 將 二退化ノ㭏轉 7 取ルガ 如キ形э是シ，烧腎八

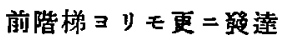
ス.脊䯓骨及ビ胸部其 ノ他ノ諸骨, 原基モ一 段卜軟骨化七ル , R.D.

P.A.

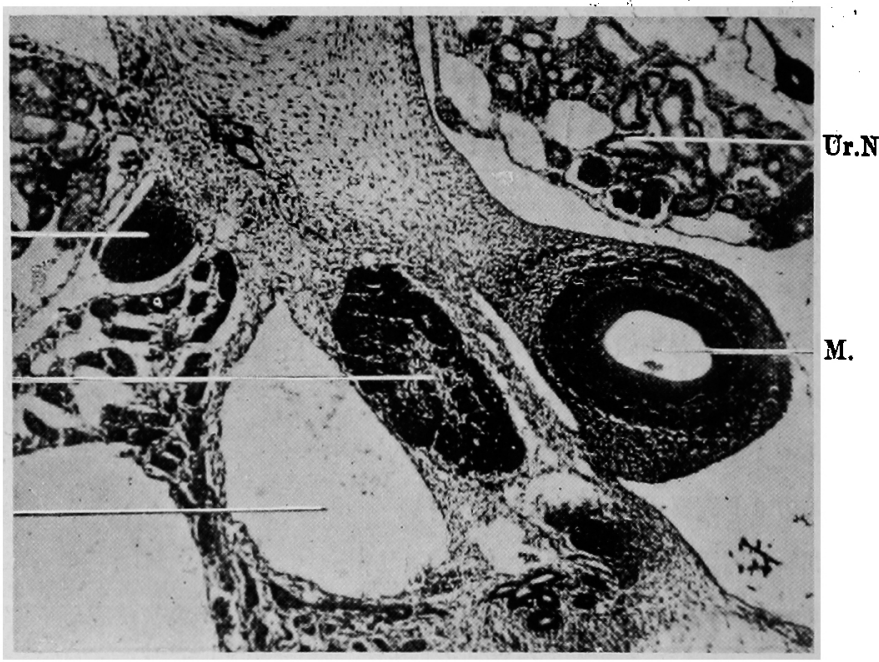
2 .

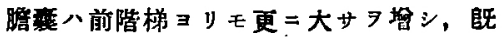
ニ多クノ血管ノ分布习認メテ Fig. 10. A = 見ル如ク多ク/肝管八集合シテ1本ノ肝管 トナリ腸／右侧背方二於テ䭪卜交通 ス。

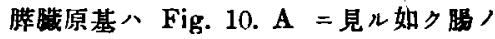
背侧右方 $\mathbf{3}$ リ小管腔狀 7 呈三前階梯卜问㥞 =背頭方=出デ，多ク/腺 7 分岥シ且分岥 七ル腺八更二分岐ヨ出シテ，愈々梅雜ナル 形 7 景シ門脈／左侧二至り更二背䌿方二進 ミ門腿，背方 $=$ 至ル。

コレア模型二就キ見ルニ肝管八右嘼方 3

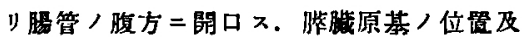

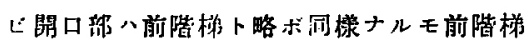
ヨリモ更二其，開口部肝管=接近 万。而之 テ其，腺分岐八公公々腸管一，開口部=向ッ

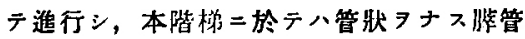
八䑏原基全長ノ約 $1 / 10$ ノ長サトナリ極丈 テ短縮 ス。而シテ其八腺分岐八棰メテ膨大シ，且 右右ノ方向二少シク眼店七ラレタル形习是シ，之

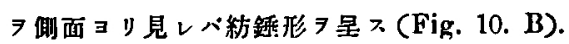

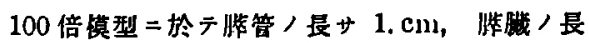
徑 $9 . \mathrm{cm}$, 原》 $1 . \mathrm{cm}$ 韦 .

例（2）胎兒距號 Nr. 20 長便 $12.0 \mathrm{~mm}$

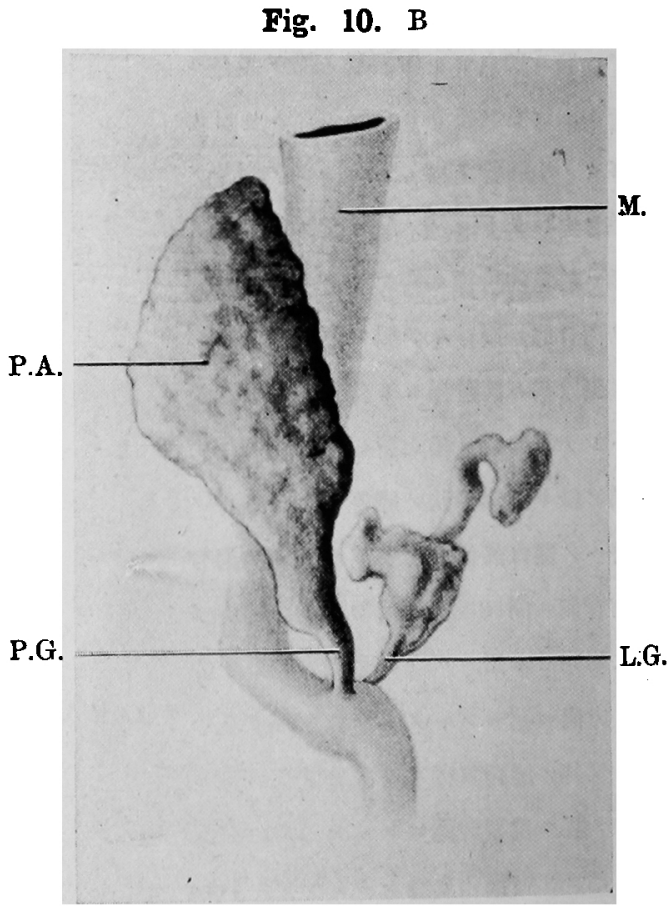

胎兒 /外形及ビ大サ各䑏器，弱生狀態略ボ例 1

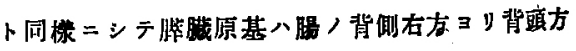

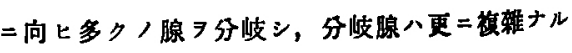
分岐 シナシテ Fig. 10. $\mathrm{C}$ 二見ル如ク胃原基/右

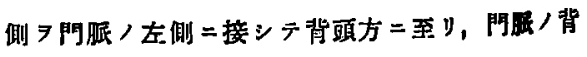
方二終り周園組織卜ノ區別明カナり。 
Fig. 10. $\mathrm{C}$

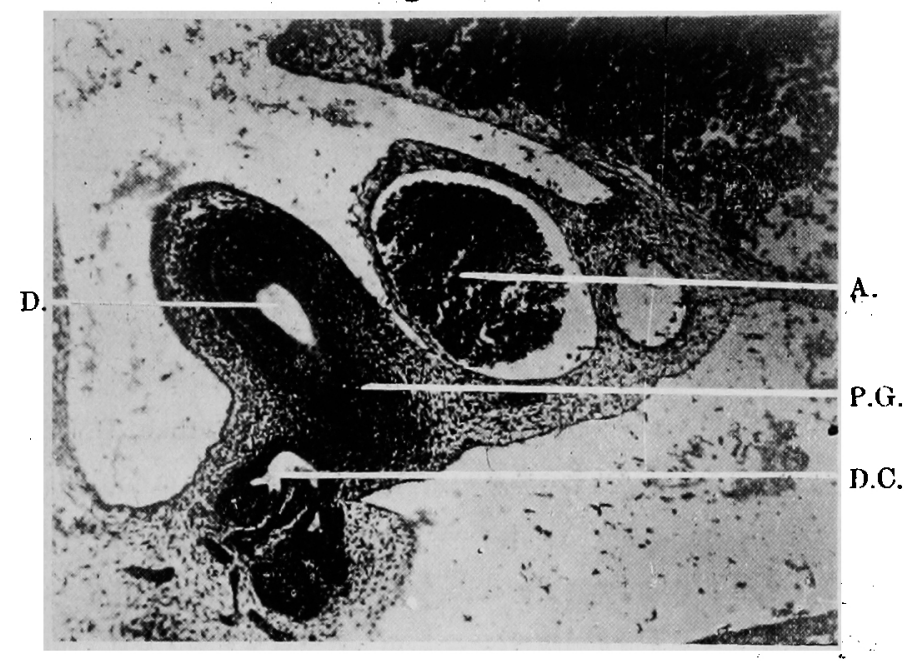

\section{第 4 章 總括站二考按}

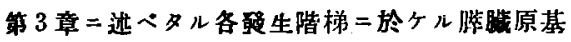
ノ發生狀態ノ所見 7 總括スル $2.5 \mathrm{~mm}$ /䏩兒二於テ八第 11 乃至第 13 原節 $/$ 高

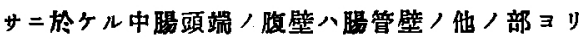

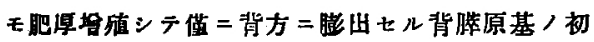
現 7 見タリ。第 2 階梯 2 卷. 長徑 $4.0 \mathrm{~mm}$ 人胎兒 ニ於テ八背搼原基八第 10-12 原節二於テ渴管， 背㑡 $コ$ 第 1 階梯二於々ルヨリモ更 $=$ 背方 $=$ 膨出

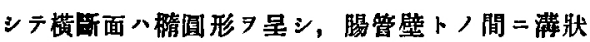
フ呈スルニ至リ、 又肝管ガ腸管二開口七ル尾方第 10-12原節 ノ高サノ腸管ノ腹側右方二坽ヶル晹管

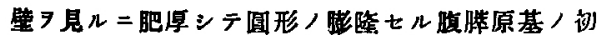
北习是をり。

更二第 3 階梯 2 参. $4.0 \mathrm{~mm}=$ 至リテハ北膜原 基八第 10 原節 /尼端乃至第 12 原㹮/頭端，高サ 二於テ渴管ノ背側 $コ$ 背右方二向ツテ膨出シテ、

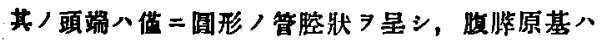
肝管/晹管開口部，尾端第 11 原的，高サ＝於テ

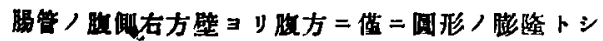
テ照ネラル.

第 4 階梯 3 先. 長徑 4.0 崛 /胎兒二於テ八背捗 原基へ肝管ノ腸管二開口七ル高サ＝於テ渴管ノ背

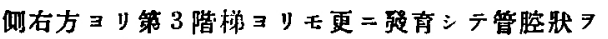
旺シ, 背方=向七門脈ノ左側二接シテ背頙方 $=$ 進 ミ門脈，左背方二至り盲管狀二終リテ先端八僅二

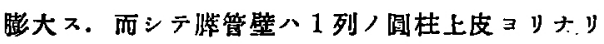
テ頭部ニ八多クノ細胞，Mitose 7 見タリ．腹临 原基八背搭原基，腸管開口部 3 り稍々顽方／位 置二於々儿晹管，愎側右方，朋管尾端二於テ第 3 階梯ヨリモ稍々分化進展シテ闽形ノ小隆起トシテ

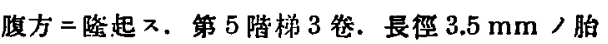
見二於デ八背滕原基八第 4 跸梯二於ヶルト同㥞位 置入晹管背侧稍々右方 $コ$ 管腔狀

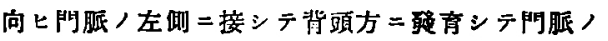
背方 $=$ 至りテ膨隆シ，僅二腺分肢 7 出シテ宣露肰 二終リ，䧗膦原基八肝管，尾端腹䀧右方 $=$ 第 4

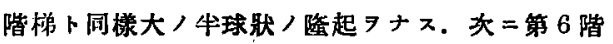
梯 $3 \mathrm{I} / 2$ 焱. 長徑 $4.5 \mathrm{~mm}=$ 至リテハ, 背集原基八 肝管開口部/高サ二於ケル腸管，背側右方壁 $コ$ リ 国形ノ谐管トナリ背方二向ヒ門脈左侧＝接シテ背

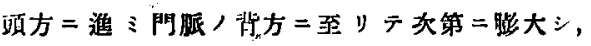
第 5 階梯ヨリモ更二弱洼七ル多ク，腺 7 分岐シテ 其八周圈八細胞 7 以テ被八儿，腹璄原基八第 5 階 梯ニ於ケルガ如ク肝管ト腸管トノ界 $ョ$ リ更二肝

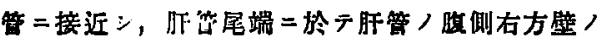


兟方二膨隆シテ第 5 階梯ヨリモ退化セルノ狀 7 是 ス. 第 7 階梯 4 尞. $5.5 \mathrm{~mm}$ (長徑) ）胎兒二於 八，背搭原基八肝管艻腸管二開口セル高サノ腸管

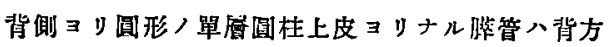
二向七門脈，左莭＝接シテ多ク，腺 頭方二進:，門脈，背侧二至り更二多夕／腺分岐

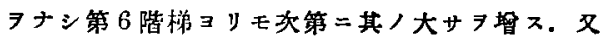

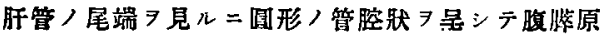
基卜思惟スべキモノハコレタ認ムルコト能ハザル 二至レリ、第 8 階梯 4 厽. $6.5 \mathrm{~mm}$ /胎兒二於テ 八䑏原基八背㗪原基ノミトナリ，第 7 階梯卜同様

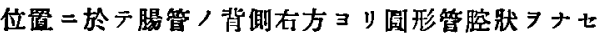

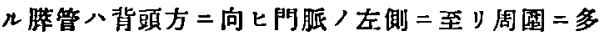
クノ腺分岐

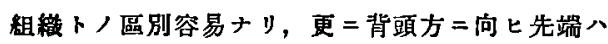
門脈, 背側二至り第 7 階梯 $コ$ モ更二複稚ナル腺

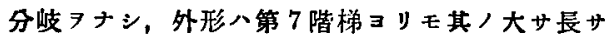
7星シテ起首部二於テ概国形 7 呈シ，顕方八僅二

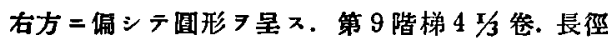
$11.0 \mathrm{~mm}$ ，胎兒二至リテ八搭管八腸管，背侧右方 ヨリ圆形ノ小管腔狀 7 呈シテ背謴方 $=$ 向七門脈， 左侧 =至ルヤ第 8 階梯 $コ$ リ更二多ク，腺分波

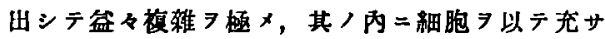

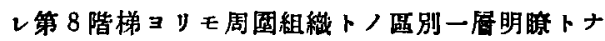
y，門服／在側 7 背頭方 $=$ 向 七門脈 $/$ 背侧 $=$ 至

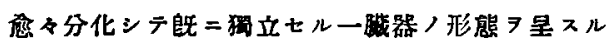
二至几，而シテ第 8 階梯 $コ$ リ更二其ノ大サ 7 管

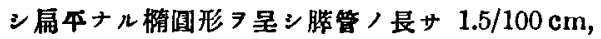

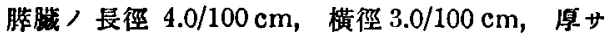

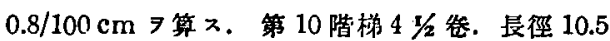

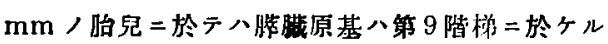
卜同樣二腸管／背側右方 $コ$ 小管腔狀 $=$ 出デタル

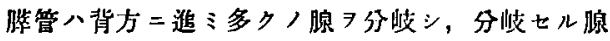

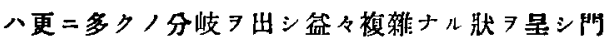
脈 /左側二至り更二背愐方二進 :テ門脈 $/$ 北方胃 原基/右背方二至り，形八启本ナル紡狳形 7 是シ テ搭管八籍 8 階榒ヨリ短カク $1 / 100 \mathrm{~cm}$ ニシテ䑏

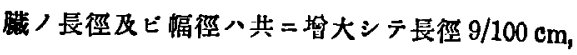
幅徑最大ナへ E $3 / 100 \mathrm{~cm}$, 原徑 $1 / 100 \mathrm{~cm}$;有 スルニ至レリ.

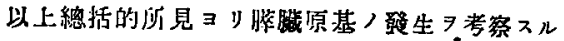
二，爬品類蝮蛇 =於テハ 1 简，背腈原基及ビ 1 筬

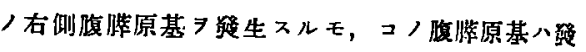
育途上退化消失シテ背㗪原基ト融合スルコトナク 背燃原基ノミ登育進展スルモノナリ，背愺原基， 發生二就テ $八$ Rathke, Hoffmann, Saint-Remy, Brachet 氏等， Colubernatrin, Edidechse, Coluber 及ビ Viper Jacerta =就テ見タル如ク 又 Orru, Völker, 大橋氏等 / Gongylus, Iacerta

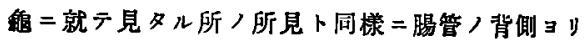

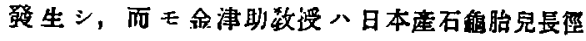

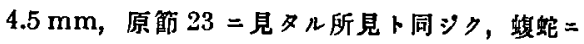
於テハ長徑 $2.5 \mathrm{~mm}$ ，胎見二於テ中脰頭端，正中

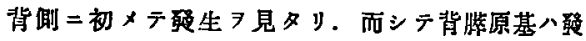
生機轉ノ進ム二從七テ圆形管狀ノ搭管 背方 $=$ 進、, 門胍/左側 7 背頭方 $=$ 僬 33 癸. 長 徑 $3.5 \mathrm{~mm}$ ，胎兒二於テ初メテ其／先端分岐シ， 之ョリ腺分岐八次第 $=$ 背搭原基基部 $=$ 向ツテ道展

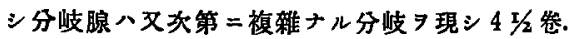
長徑 10.5-12.0 mm /胎兒二至リテ八格ボ完成， 䑏脿/外形二近似七ル形 7 圼シ，周圈ノ組蟣卜完

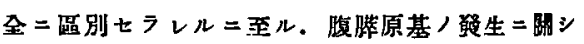
テハ，從來諸家ノ意見一政セズ Völker 氏/如ク Lacerta $\exists$ 村料卜シテ研究シ腹搭原基/敢生 $尹$ 不 定シタルモノノ如ク，Saint-Remy, Brachet 氏等

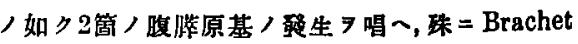
氏八Lacerta =就キ肝管開口部/左右雨㑡 $=$ 政生 シテ敢青ストナスモノアリ. 然ル $=1899$ 年 Orru

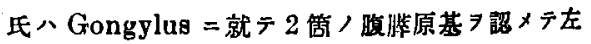
側ノモノ八敢生ノ進么二從七テ，濑次右側二移動 スト唱一タリ其，他 Weber, Siwe, 大橋氏等八共

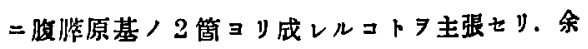

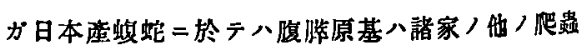

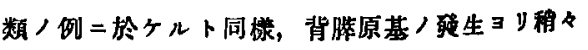


暒レテ 2 䓡. 長徑 $4.0 \mathrm{~mm}$ ノ胎兒二於テ只 1 筒

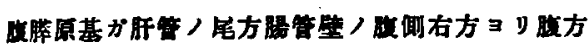

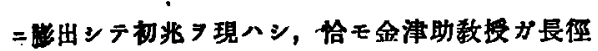
$4.5 \mathrm{~mm}$, 原简数 2.5 , 石争胎兒二見タル所見二仙

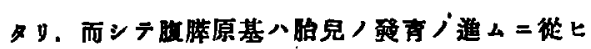
所管尾端二近接ンテ 3 管. 長俓 $3.5 \mathrm{~mm}=$ 至リテ

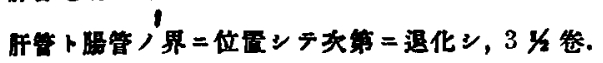

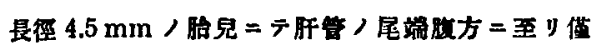
$=m$ 方 $=$ 洼起 テ退化消失スル

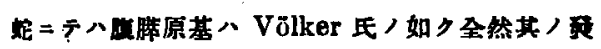
生 7 百定 スルモノ=韭ズ. 又 Weber, Siwe, 大檽

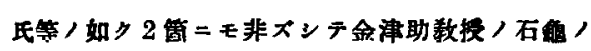
例ノ如ク右側=只 1 简登生セル

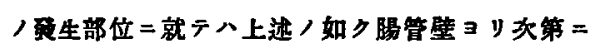
仟管尾端二入ル點ヨリ考按スレベ大榙氏等ノ唱つ

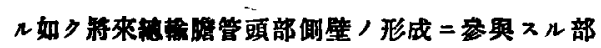
城內一震生スnモノ，如シ。

\section{第5章結論}

前章二於ヶル続括及ビ考察二依り久ノ結猃 7 得

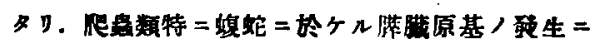
就テ气

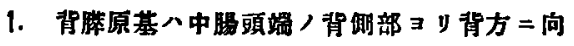

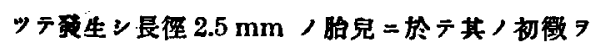
嘼メタリ。

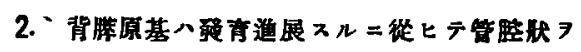

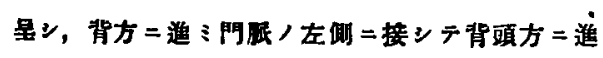

ミ， 3 卷. 展徑 $4.0 \mathrm{~mm}$ 强，胎兒二至リテ門腿， 背方二至り先端目端二䊏ル。

3. 背䑏原基八萁/先端 $\exists$ y起首部 $=$ 次第 $=$ 腺 分岐

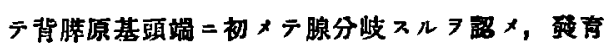

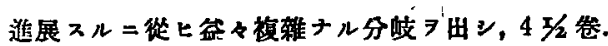

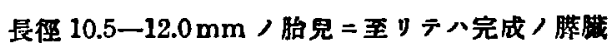
二近似七ん形 $\boldsymbol{ー}$ ナニ至ル。

4. 膜原基八肝管／尾端二於ヶル血侧右方，

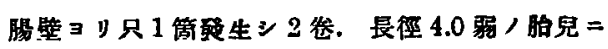
於テ其ノ初徽

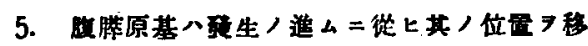

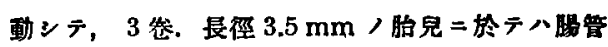

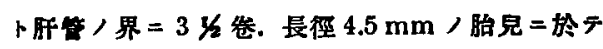
八肝笋，尾端敗方二現八ル。 サレト長徑 $4.5 \mathrm{~mm}$

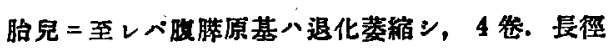

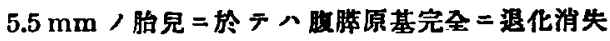
ᄌ.

6. 蛽蛇 =於ヶル蕠荟原基八他ノ爬数ノソレ

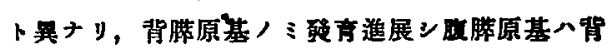

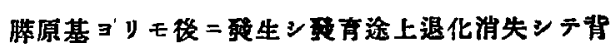
䑏原基ト憵合スルコトナン。

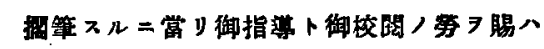

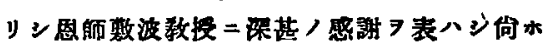

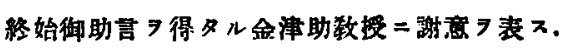

\section{文音}

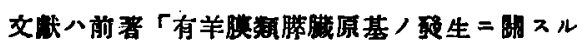

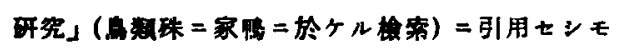
ノ同 $シ$. 
Fig. 1. 第 1 階梯 (Nr. 34)

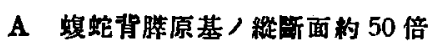
B 同上模型右例面粯 (100/1) $1 / 2$ 縮第

Fig. 2. 第 2 階梯 (Nr. 3)
A 同上猆滕原基，横所面的 50 倍
B 同上腹滕原基，横丽面約 50 倍

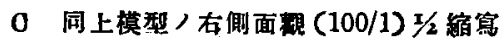

Fig. 3. 第 3 階梯 (Nr. 2)
A 同上背㳟原基，横断面的 50 倍

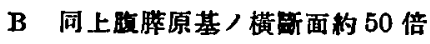
C 同上模型／右侧面覞 (100/1) 3/2 縮富

Fig. 4. 第 4 跸梯 (Nr. 36)
A 同上䐈膜原基，箱面的 50 倍
B 同上背滕原基八背㑡断面粎 50 倍
0 同上模型／右㑡面䄄 (100/1) $x / 2$ 縮管

Fig. 5. 第 5 階梯 (Nr. 42)
A 同上背櫒原基/先端略面約 50 倍
B 同上腹搭原基，断面約 50 倍 -
C 同上模型/右侧面鹤 $(100 / 1) 5 / 2$ 縮管

Fig. 6. 第6 階梯 (Nr. 40)
A 同上腹搭原基，斷面約 50 倍
B 同上背搭原基，先端铒面䄪 50 倍

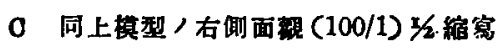

Fig. 7. 第7階梯 (Nr. 46)
A 同上背滕原基/起始部所面约 50 倍
B 同上背膵原基／先端嗞面

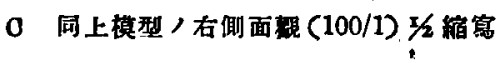

Fig. 8. 第 8 階梯 (Nr. 49) 。
A 螘蛇背蕠原基/横断面的 50 倍

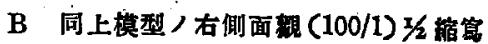

Fig. 9. 第 9 階梯 (Nr. 33)
A 同上背膡原基，所面粎 50 哄

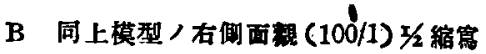

Fig. 10. 第.10階梯 (Nr. 32)

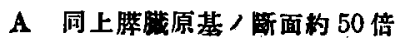

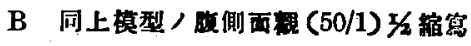
o (例 2 Nr. 20)

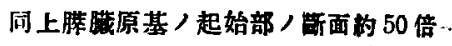

A. $=$ Aorta. $\quad$ D. $=$ Darm. $\quad$ D.C. $=$ Ductug , Choledochus. D.P. = Dorsale Pankreasanlage. D.S. = Dottersack. $\quad$ GBB. = Gallenblase. $\quad$ Ka. Lg. = Kaudale Lebergang. Kr.Lg. = Kraniale Lebergang. L.A. = L,eberanlage. L,G. = Lebergang. L.V.P.=Linke ventrale Pankreasanlage. $\quad \mathrm{M}_{.}=$Magen. $\quad \mathrm{Pf} .=$ Pfortader. P.G. = Pankreasgang. $\quad$ R.V.P. $=$ Rechte ventrale Pankreasanlage. $\quad$ R.M. = Rückenp̣arark. Ur.N.=Urniere. V.D. $=$ Vorderdarm. V.P. $=$ Ventrale Pankreasanlage.

Aus dem Embryologischen Laboratorium des Anatomischen Institutes đer Med. Fakultät Okayama (Vorstand: Prof. Dr. J. Shikinami).

Studien über die Entwicklung der Pankrasanlage bei Amnioten. Studien bei Reptilien, besonders bei der Kreuzotter. Von Mitomo Tasaka. = 
Verf. hat sich mit vergleichenden Untersuchungen der Entwioklung der Pankreasanlage der verschiedenen Amnioten beschaftigt. Was diese Untersuchungen bei Amnioten betrifft, so ist oine solche fur Saugetiere schon mit Kaninchen eingehend angestellt worden. Hier wird die Entwicklung der Pankreasanlage bei der Kreuzotter als Beispiel fur Reptilien erforscht. Die Resultate sind in folgender Weise zusammenzufassen :

1. Die dorsale Pankreasanlage entsteht vom Dorsalteil der Spitze des Mitteldarmkopfes aus und entwickelt sich dorsalwarts, beim Embryo von $2.5 \mathrm{~mm}$ Durchmesser ist das erste Zeichen derselben schon wahrzunehmen.

2. Die Entwicklung der dorsalen Pankreasanlage erfolgt in der Art, dass sie rinnenförmig auftritt und dorsalwarts fortschreitet. Dann entwickelt sie sich knapp an der rechten Seite der Portader dorsal nach dem Kopf, um dann endlich beim Embryo von 3 Rollen und etwas mehr als $4.0 \mathrm{~mm}$ Durchmesser in der Dorsalseite der Portader blind zu ender.

3. Die Drusenverzweigung der dorsalen Pankreasanlage fangt an der Spitze der latzteren an und schreitet allmahlich nach dem Ausgangspunkt fort. Diese Drüsenverzweigung wird an der Spitze des Pankreaskopfes des Embryos von 3 Rollen und $3.5 \mathrm{~mm}$ Durchmesser zum ersten Male konstatiert. Je Weiter die Entwicklung fortschreitet, desto komplizierter wird diese Drusenverzweigung. Und zwar zeigt die Pankreasanlage beim Embryo von 4.5 Rollen und $10.5-12.0 \mathrm{~mm}$ Durchmesser endlich eine dem vollendeten Pankreas ahnliche Gestalt.

4. Die ventrale Pankreasanlage entsteht von der rechtsseitigen ventralen Wand des Darms aus, der sich an der Schwanzspitze des Lebersganges befindet, und ihr erstes Zeichen kann schon beim Embryo von 3 Rollen und etwas weniger als $4.0 \mathrm{~mm}$ Durch. messer gefunden werden.

5. Die ventrale Pankreasanlage verandert mit dem Fortschreiten der Entwicklung ihre Lage, und zwar beim Embryo von 3 Rollen und $3.5 \mathrm{~mm}$ Durchmesser in die Grenze des Darmganges und Leberganges und beim Embryo von 3.5 Rollen und $4.5 \mathrm{~mm}$ Durchmesser nach der ventralen Seite des Schwanzes des Leberganges, um endlich beim Embryo von 4 Rollen und $5.5 \mathrm{~mm}$ Durchmesser vollkommen zu entarten und $\mathrm{ku}$ verschwinden.

6. Bei der Pankreasanlage der Kreuzotter entwickelt sich verschieden von anderen Reptiliern nur die dorsale, dagegen entsteht die ventrale nicht nur spater als die erstere, Bondern kommt auch auf dem Wege der Entwicklung zum Entarten und Verschwinden. Keinewegs verschmilzt die ventrale mit der dorsalen. (Autoreferat) 